\title{
What to Say to Those Who Stay? \\ Free Movement is a Human Right of Universal Value
}

\author{
Kieran Oberman
}

Free movement is under attack, both within Europe and at the frontier. Within Europe, we are witnessing Brexit, Swiss discontent with EU migration and the electoral rise of the far right. At the frontier, free movement has never fared well. The EU has always been something of a gated community, allowing insiders to move while keeping outsiders out. The only difference now, with wars in Syria, Afghanistan and elsewhere, is the higher numbers seeking entry and the higher numbers dying in the attempt. How has Europe responded? The current drive is to reinforce the borders, while calling on 'safe' third countries, such as a Turkey, to house refugees. Expect more deaths and more misery in the years to come.

It is a good time then to be raising Floris de Witte's question: is free movement worth defending? Like De Witte, I think the answer is definitely 'yes', but I offer a different line of argument. For De Witte, free movement is important in encouraging Europeans to change their values: to move away from a narrow concern with nations, membership and exclusion and towards a cosmopolitan regard for multiple identities and 'anchorless' belonging. While this a fascinating and original take on free movement, it seems unnecessarily complex and controversial. Not everyone will accept the cosmopolitan ideological stance it assumes and even those who do might question whether free movement is either necessary or effective at promoting this ideology. The argument I offer is simpler and, in one important sense, less controversial. It defends free movement not as means to change values but rather as an extension of the values we already hold. It also offers reasons for why those who stay in their country of origin should nevertheless value their freedom of movement.

\section{The human right to immigrate}

Democratic societies place significant emphasis on basic liberties. These basic liberties are protected in international law. The Universal Declaration of Human Rights (UDHR) and the International Covenant on Civil and Political Rights (ICCPR) lists rights to freedom of religion, expression, 
association, marriage and occupation. These rights are essential to protecting people's personal and political liberty. In terms of personal liberty, they entitle people to make basic life decisions such as whom they marry, which (if any) religion they practice, with whom they associate, where they work and how they communicate. In terms of political liberty, they make it possible for people to engage in crucial political activities such as investigating the effects of government policies, debating solutions to social problems and campaigning for change.

Free movement is important because it is prerequisite to the exercise of these other basic liberties. People cannot worship, communicate, associate, marry and work freely unless they are able to move freely. Recognizing this fact, international law declares a right to free movement. Article 13 of the UDHR and Article 11 of the ICCPR proclaim a right to free movement within any country and a right to leave any country to go elsewhere.

There is one right, however, that is conspicuously absent: the right to immigrate. This is a problem since immigration restrictions, no less than emigration restrictions and internal restrictions, curtail personal and political liberty. When foreigners are prevented from entering a country, they are prevented from worshiping, communicating, associating, marrying and working within that country. Their freedom, as well as the freedom of consenting citizens, is constrained. Individual autonomy suffers but also democracy. In an age in which so many problems are international problems and the effects of government policies are felt globally, it is crucial that citizens of different countries are permitted to interact. The power of governments and corporations transcend borders; ordinary people must not be trapped behind them.

If personal and political liberty are to be sufficiently protected, immigration must be recognized as a human right. In recognizing immigration as a human right, we discover the full value of EU free movement. Not only does free movement allow EU citizens to freely interact, it also provides a model for the rest of the world. In time, the world can and should follow Europe's example.

There are other implications that are less flattering to the EU project, however. Human rights are universal. If EU citizens have a human right to immigrate to other EU states, non-EU citizens do likewise. The Syrians, Afghans and others at the frontier must be free to enter. Refugees have a right to live where they choose, not just the 'safe' third countries to which the EU seeks to confine them. Indeed, all migrants have a right to migrate not just refugees.

Floris de Witte's article thus starts out exactly right. Retired teachers, Romanian IT consultants, Hungarian nurses and everyone else should be able to make basic decisions regarding their lives free from state interference. 
That is what is crucial. There is no need to add that free movement encourages people to achieve a new 'self-understanding' as 'anchorless' EU citizens. The value of free movement is both more basic and more important.

\section{The freedom to stay}

The discussion following Floris De Witte's article has been fascinating and I have learned a great deal. Let me address two points. First, it is striking that, in the midst of a refugee and migration crisis, the discussion should have focussed so narrowly on free movement within the EU. Sarah Fine is certainly right to remark on this, asking 'whose freedom of movement is worth defending?' If the EU is not to forever remain a gated community, we must not ignore the gates.

Second, a number of contributors have raised an important problem: how can supporters of free movement demonstrate its value to those citizens who do not migrate? Floris de Witte distinguishes between 'mobile' and 'immobile' citizens; a distinction that Rainer Bauböck picks up on. He wonders how the 'immobile' can be won over? The problem is an important one but, in its general form, is far from new. A central theme of what remains the greatest book on the subject of liberty - JS Mills' 'On Liberty' - is the problem of justifying the freedom to pursue minority options to the disinterested majority. The answer Mill gave then still holds true today. There is an enormous difference between choosing not to pursue an option and being prevented from pursuing it. In the former case, one retains control and, with it, the opportunity to assess how one lives in comparison to alternative possibilities. In the latter case, one never makes a choice; one's life is dictated by others. Consider the point in relation to freedom of religion. One does not have to be a religious Jew (say) to regard a state ban on Judaism as a violation of one's freedom of religion. One's freedom of religion entitles one to have the option to practicing Judaism, even if one never chooses to pursue it. The option is important because in having it one has a source of control over one's life that is rightfully one's own.

There is a further point to be made, however. It is not only that people who stay have an interest in the option of moving. People who stay are actually exercising the same basic liberty as the people who migrate: their freedom of movement. This point is too easily missed. People tend to assume that freedom of movement is all about movement, when in fact freedom of movement includes the freedom to stay. Freedom of movement entitles one to control over one's movements. To have control, one must be able to decide not just where to move but whether to move. The point is not purely conceptual. Freedom of movement encompasses the freedom to move and to stay because the same set of interests are at stake in each case. People's 
personal and political liberty depends as much on the freedom to stay as the freedom to move. We cannot make our own life decisions and engage in free political activity unless we are free to stay and to move as we wish.

It is easy to picture the free movement debate in terms of stereotypes: the 'young Euro jetsetters' vs. the 'resentful go-nowhere locals'. It is also easy to assume that freedom of movement is all about the movers and offers nothing to the stayers. But we need to think again. From a normative perspective, there is no sharp contrast. When we move or when we stay we are engaged in the same core activity: deciding how we spend our lives and with whom. Whatever choices we make, and wherever our choices take us, we should all be able to see how important it is that our choices are our own.

Having come this far, we can now discern something misleading in De Witte and Bauböck's terminology. The 'immobile' category is much too broad. It lumps together people who, due to poverty and other social barriers, cannot move with people who simply choose not to. In the case of the former, the correct response is to make free movement an effective rather than merely formal freedom by tackling poverty and other social barriers to movement. In the case of the latter, the correct response is to remind these people that they are not, in fact, immobile. They have made a choice about where they live and, thereby, exercised their freedom of movement. They should now allow others to do likewise.

Of course, providing a philosophical argument for why everyone should value freedom of movement is not the same as actually convincing them. After Brexit, the latter task appears daunting. But the problem we face is, in at least one sense, easier than the problem Mill faced in his day. Mill had to convince people of the value of basic liberties. In our day, most people accept the value of basic liberties; they just fail to realize their full implications.

Open Access This chapter is licensed under the terms of the Creative Commons Attribution 4.0 International License (http://creativecommons.org/licenses/by/4.0/), which permits use, sharing, adaptation, distribution and reproduction in any medium or format, as long as you give appropriate credit to the original author(s) and the source, provide a link to the Creative Commons license and indicate if changes were made.

The images or other third party material in this chapter are included in the chapter's Creative Commons license, unless indicated otherwise in a credit line to the material. If material is not included in the chapter's Creative Commons license and your intended use is not permitted by statutory regulation or exceeds the permitted use, you will need to obtain permission directly from the copyright holder. 